covery of common truths rather than simply to the satisfaction of curiosity concerning the odd ways other people do things which we do differently or to the confirmation of prejudices and stereotypes concerning alien errors, illusions, and depravities."-Eugene H. Wilson, University of Colorado.

\section{The New Ulrich}

Ulrich's Periodicals Directory; a Classified Guide to a Selected List of Current Periodicals, Foreign and Domestic. 9th ed. Edited by Eileen C. Graves. New York: R. R. Bowker, 1959. 825p. \$22.50.

The appearance of a new edition of Ulrich's is always a welcome event. Its tremendous fund of information, up-to-date, difficult to find elsewhere, handily arranged and packaged, is a basic reference work for every library, large and small. The ninth edition has some new features, and has expanded some old features that add even more to Ulrich's usefulness: there is a new list of indexing services; a more inclusive list of "Abstracts and Abstracting Services"; a new selected list of newspapers, foreign and domestic, with addresses and circulation figures; nineteen new categories of subjects have been added; the subscription prices, when known, are given in United States currency and, of course, the number of titles included has increased, with approximately one thousand titles new to this edition. The large number of advertisers is not only a tribute to the book's reputation, but provides a handy source of names of agents and dealers.

A serials librarian reviewing Ulrich's is not unlike a member of the clergy reviewing the New Testament. To us who continually need information about the prices, addresses, indexing, etc. of periodicals it is somewhat of a bible. Yet it should not be likened too closely to gospel, for it does have its shortcomings. So that it will be used with a certain amount of caution and so that future editions may be improved, these should be pointed out.

A book published by Bowker, priced at $\$ 22.50$, and a standard reference work for every library, should be as free as possible of errors. It augurs poorly for such an im. portant work to see on the very first page of text the phrase "is in ifself" (page v), to read a little farther on that the Indexing Services are on page xi when they are actually on page $x v$, and to note other errors and misprints in the prefatory pages. There are many misprints: on page 297, for example, Arctic is spelled "Artic" four times; some titles in the index are out of order and thereby virtually lost. These few examples are minor, perhaps, but they should not have been permitted.

There also are numerous errors in the bibliographic information. A relatively small number of the total titles were checked, but in these there were enough errors to be disturbing. For example: the Geographical Journal started in 1893, not 1883, and is published quarterly, not monthly; Good Housekeeping began in 1885, not 1855; Ecology in 1920, not 1897; the Current History that is current began in 1941, not 1914; Anjou historique ceased publication over two years ago, Confluence over a year ago. Perhaps these also are minor, but again most of them should have been caught.

A number of periodicals seem to have been classified by their titles or subtitles, or by their sponsors, rather than by their actual contents. For example, the American Journal of Philology is under "Literature and Philology," while the Philological Quarterly: Devoted to Scholarly Investigation of the Classical and Modern Languages and Literatures is under "Classical Studies." Actually, the former periodical emphasizes classical studies, and the latter modern philology. Manuscripta is concerned with "Literature and Philology" only as it is with other subjects in which the use of manuscript materials is important and, as a matter of fact, it has not carried any articles on literature in its three years. House and Home deals with "Interior Decoration" only incidentally -that is, if such decoration would help to sell the houses built by the magazine's readers, who are builders and architects. Daedalus, published by the American Academy of Arts and Sciences, is a general periodical with a much broader scope than "Natural and Physical Sciences."

Ulrich's is a "selected list," and the editor's criteria must be respected. From the viewpoint of a university library, however, 
many titles one expects to find are missing. One medium-sized university library checked subscribes to almost two hundred periodicals in the field of biology (excluding medicine). This is not an outstanding collection, by any means, but it is a very respectable one and includes most of the important titles in the field. Of these titles, over thirty do not appear in Ulrich's, including such important journals as Annales botanici, Archives de zoologie experimentale et génerale, Cellule, and Zeitschrift für Biologie. Proportions of other fields checked were better, but such standard titles as the Classical Weekly, Journal of Bible and Religion, and Music Library Association Notes ought not to be omitted when seemingly every periodical relating to flying saucers, including such an improbable title as Thy Kingdom Come, is carefully listed. The problem of selection is undoubtedly the toughest faced by an editor of such a reference work. The only logical attempt at a solution is to concentrate on thoroughness of coverage in the type of material for which the volume will be most consulted (and this comment is only from the point of view of the university librarian) and to include others only in so far as time and expense permit.

This raises another question. It is difficult to draw a strict line of definition between periodicals and other serials. But it must be drawn this side of the Union List of $\mathrm{Se}$ rials, Literary Market Place, and Deutsche Presse. It should, in my opinion, also be drawn this side of monographic series and academy transactions, unless they appear fairly frequently and with some regularity as do not, for example, the Memoirs of the American Mathematical Society or the Smithsonian Miscellaneous Collections. With the constantly increasing number of national and subject bibliographies, information on monographic series is relatively easy to find. Because of this, it is unfortunate that so many periodicals are omitted and so many other titles not primarily within the scope of the book are included.

There are some changes in form that may be suggested. "Price not given" appears too frequently. If the periodical can be obtained free, this should be stated, even if it must appear (as it does under a number of entries) as an uncertain "Free?" If the price varies, the approximate annual cost might be estimated. To be sure, this is often a ticklish proposition, but Ulrich's is consulted for prices as much as any other information. (Incidentally, prices should be added to the information given in one of the very useful new features, the list of newspapers.) Another helpful addition would be to give for each periodical the most recent volume number and date. Finally, I would like to see entries consistent with LC in form and capitalization.

After all critcism, I can only say that the usefulness of Ulrich's is beyond question. This is not intended as a mere palliative, and if $I$ have not made a point in repeating its virtues, it is only because we have all been so dependent on it that we are familiar with them, and grateful for them. I hope, however, that some of the limitations pointed out will help in its use, and possibly serve its compilers to make future editions even more valuable.-Evan I. Farber, Emory University Library.

\section{Soviet Libraries}

Libraries and Bibliographic Centers in the Soviet Union. By Paul L. Horecky. (Indiana University Publications. Graduate School. Slavic and East European Series, v. 16.) [Bloomington, Indiana] Indiana University Publications [1959]. 287p.

Mr. Horecky's book is timely. The increased interest in Soviet contributions to science, and the growth in the purchases of Russian books and the exchange activities between American and Russian libraries have created a desire for a thorough knowledge of the Soviet library system and the demand for a publication presenting a detailed and systematic description of Soviet libraries and bibliographic centers. The articles on various aspects of Soviet libraries which have appeared in American library periodicals and the UNESCO Bulletin for Libraries from time to time, although shedding much light on the topic under review, could not entirely satisfy the demand for an organized picture of the entire library system. 